\title{
PENDIDIKAN KARAKTER DI INDONESIA DALAM TINJAUAN PSIKOLOGIS
}

\author{
Noormawanti \\ Program Studi Pendidikan Agama Islam \\ Fakultas Agama Islam Universitas Muhammadiyah Metro \\ Email noormawanti13@gmail.com
}

\begin{abstract}
Abstrac
Character education can be interpreted simply form the character, temperament, character and personality of a person by instilling noble values, so the values are ingrained, united in heart, mind, word and deed and showed its influence in the reality of life is easy, on his own, original and as sincere for Allah alone. Planting and personality formation was carried out not only by giving understanding and change mindsets and patterns of view of someone about something that is good and true, but good values are socialized, trained, exemplified, performed continuously and practiced in the daily lives day. Psychologically humans are per se there are various psychological tendencies or dislike something. Psychologically man happy about new things, funny and intriguing. Besides humans also have the feeling of wanting to be appreciated, wanted company, want to be praised, to be given a gift or something and so forth. Thus the human psychological state that it should be used as a door to instill the values of character education. The tendency of human psychology so it has been responded to and used by the Qur'an carefully in instilling the values of character education.
\end{abstract}

Key Words : Education, Character, psychologi

\section{PENDAHULUAN}

Indonesia memerlukan generasi muda penerus bangsa sebagai sumber daya manusia yang berkualitas, dalam jumlah dan mutu yang memadai sebagai pendukung utama pembangunan, yang salah satunya diperoleh dengan kegiatan pendidikan. Hal ini berdasarkan Undang-Undang No 20 Tahun 2003 Tentang Sistem Pendidikan Nasional pasal 3, bahwa pendidikan nasional berfungsi mengembangkan kemampuan dan membentuk karakter serta peradaban bangsa yang bermartabat dalam rangka mencerdaskan kehidupan bangsa. Pendidikan nasional bertujuan untuk berkembangnya potensi peserta didik agar menjadi manusia yang beriman dan bertakwa kepada Tuhan Yang Maha Esa, berakhlak mulia, sehat, berilmu, cakap, kreatif, mandiri dan menjadi warga negara yang demokratis serta bertanggung jawab. ${ }^{1}$

Dapat dikatakan bahwa Indonesia memerlukan manusia yang tidak hanya cerdas dalam bidangnya, tetapi juga berkarakter/berwatak agamis, mampu menjunjung tinggi nilai-nilai agama dalam kehidupan. Di era globalisasi seperti

\footnotetext{
${ }^{1}$ Undang- Undang Sistem Pendidikan Nasional, Jakarta: Sinar Grafika, 2007, h. 7.
} 
sekarang ini, dunia pendidikan dihadapkan pada berbagai tantangan, diantaranya penjajahan baru dalam bidang kebudayaan (new colonization inculture), dan tuntutan masyarakat tentang perlunya penegakan hak-hak asasi masnusia serta perlakuan yang lebih demokratis, adil, manusiawi, egaliter dan bijaksana. Penjajahan dibidang kebudayaan antara lain masuknya nilai-nilai budaya barat yang bercorak materialistis, hedonistik, pragmatis dan sekularistik. Akibat dari adanya pengaruh budaya barat ini, maka manusia menganggap remeh terhadap nilai-nilai spiritual, nilai-nilai transendental, nilai-nilai budi pekerti, serta nilainilai agama lainnya. Kuatnya pengaruh budaya yang bersifat kebendaan ini berpengaruh sangat besar tidak hanya bagi generasi muda melainkan manusia secara keseluruhan.

Berkaitan dengan hal ini, pendidikan memiliki andil yang sangat penting dalam memperbaiki pandanga serta pola pikir bahwa masalah keduaniawian itu bukanlah tujuan utama dalam sebuah kehidupan melainkan ada tujuan hidup yang lebih penting yakni akhirat. Dalam pendidikan perlu dimaksimalkan upaya penanaman nilai kararkter siswa dengan tujuan yang tepat, tidak hanya bersifat teoriris melainkan lebih bersifat praktis. Tidak hanya cukup pada ranah kognitif tetapi juga sampai kepada afektif.

Secara psikologis, pendidikan bukan hanya sekedar memindahkan ilmu pengetahuan atau nilai-nilai dari generasi tua kepada generasi muda, melainkan sebuah proses yang tidak sederhana. Dalam kegiatan belajar mengajar, para psikolog menganjurka hal-hal sebagai berikut. Pertama, seorang peserta didik tidak hanya sekedar menerima dalam keadaan pasif, tetapi aktif dan dinamis, malah sangat selektif dan mempunyai syarat-syarat tertentu yakni adanya rangsangan oleh seorang guru. Kedua, adanya respon terhadap rangsanga tersebut dan Ketiga, respon tersebut harus diperkuat dan diakui dalam bentuk reward, pujian,pengakuan dan lainnya. Selain itu dalam proses pendidikan juga terjadi interaksi antar individu, yaitu antara peserta didik dengan pendidik, peserta didik dengan peserta didik lainnya, peserta didik dengan lingkungan di sekitarnya. Dalam pandangan psikologi, manusia berbeda dengan makhluk lainnya, karena kondisi psikologisnya. Manusia berbeda dengan benda atau tanaman karena benda atau tanaman tidak memiliki aspek psikologi yang canggih sebagaimana manusia. Manusia juga berbeda dengan binatang, karena kondisi psikologis manusia jauh lebih tinggi tarafnya dan jauh lebih kompleks. Berkat kemampuan-kemampuan psikologis yang lebih tinggi dan kompleks inilah sesungguhnya manusia menjadi lebih maju, lebih banyak memiliki kecakapan pengetahuan dan keterampilan dibandingkan dengan binatang. ${ }^{2}$

Fuad Nashori didalam bukunya: Agenda Psikologi Islami. mengatakan bahwa komponen terpenting manusia adalah qalbu (hati nurani). Perilaku manusia bergantung kepada kalbunya yang secara fisik disebut mudghah. (Imam Ghazali sering membedakan hati fisik dengan hati ruhani). Rujukan yang sering

2 Abuddin Nata, "Ilmu Pendidikan Islam dengan Pendekatan Multidisipliner", Jakarta: PT Raja Grafindo Persada, 2010, Cet-1, h. 164-165. 
digunakan adalah sebuah hadis shahih yang diriwayatkan Tirmidzi: Sesungguhnya dalam jasad manusia terdapat mudghah. Jika mudghah itu baik, maka baiklah seluruh tubuh. Jika mudghah itu rusak, maka rusaklah seluruh tubuh. Mudghah itu adalah qalbu. (H.R Tirmidzi) ${ }^{3}$

Di samping jasad (panca indra), dan akal, manusia memiliki qalbu. Dengannya manusia dapat mengetahui sesuatu (di luar nalar), berkecenderungan kepada yang benar dan bukan yang salah (termasuk memiliki kebijaksanaan, kesabaran), dan memiliki kekuatan mempengaruhi benda dan peristiwa. Nabinabi dan Rasul-rasul adalah contoh pribadi-pribadi yang qalbunya berkembang optimal, sehingga mereka dapat mengetahui sesuatu yang tidak tampak dengan cara yang tidak biasa (melalui wahyu/ilham), tidak pernah goyah berpegangan pada nilai kebenaran, dan memiliki berbagai kemampuan mempengaruhi sesuatu.

Berdasarkan alasan-alasan di atas dan permasalahan yang telah disebutkan, maka tulisan ini akan memfokuskan pada upaya pendidikan karakter di Indonesia dalam tinjauan psikologis.

\section{PEMBAHASAN}

\section{Pengertian Pendidikan Karakter}

Pendidikan karakter secara sederhana dapat diartikan membentuk tabiat, perangai, watak dan kepribadian seseorang dengan cara menanamkan nilai-nilai luhur, sehingga nilai-nilai tersebut mendarah daging, menyatu dalam hati, pikiran, ucapan dan perbuatan dan menampakkan pengaruhnya dalam realitas kehidupan secara mudah, atas kemauan sendiri, orisinal dan karena ikhlas semata karena Allah Swt. Penanaman dan pembentukan kepribadian tersebut dilakukan bukan hanya dengan cara memberikan pengertian dan mengubah pola pikir dan pola pandang seseorang tentang sesuatu yang baik dan benar, melainkan nilainilai kebaikan tersebut dibiasakan, dilatihkan, dicontohkan, dilakukan secara terus- menerus dan dipraktikkan dalam kehidupan sehari-hari. ${ }^{5}$

Dalam bahasa Arab, kata karakter sering disebut dengan istilah akhlak, yang diartikan sebagai sifat atau keadaan yang tertanam didalam jiwa yang paling dalam yang selanjutnya melahirkan berbagai perbuatan dengan mudah tanpa memerlukan pemikiran dan pertimbangan lagi, akhlak merupakan pola tingkah laku yang mengakumulasikan aspek keyakinan dan ketaatan sehingga tergambarkan dalam prilaku yang baik. ${ }^{6}$

Dengan demikian pendidikan karakter bukan hanya sekedar memberikan pengertian atau definisi-definisi tentang baik dan buruk, melainkan sebagai upaya mengubah sifat, watak, kepribadian dan keadaan batin manusia sesuai dengan nilai-nilai yang dianggap luhur dan terpuji. Melalui pendidikan karakter

\footnotetext{
${ }^{3}$ Fuad Nashori, Agenda Psikologi Islami”, Yogyakarta: Pustaka Pelajar, 2010, h. 22.

${ }^{4}$ Ibid; h. 23.

5 Abudin Nata, “Akhlak Tasawuf”, Jakarta: Raja Grafindo Persada, 2005, h. 65-68.

6 A. Toto Suryana, Cecep Alba, E. Syamsudin, Udji Asiyah, Pendidikan Agama Islam, Bandung: Tiga Mutiara, 1997, h. 189.
} 
diharapkan dapat dilahirkan manusia-manusia yang memiliki kebebasan untuk menentukan pilihannya, tanpa paksaan, disertai rasa penuh tanggung jawab. Yaitu manusia yang merdeka, dinamis, kreatif, inovatif dan bertanggung jawab kepada Tuhan, diri sendiri dan orang lain.

Dalam al-Qur'an dan al-Sunnah lebih menekankan pada seseorang untuk membiasakan, mempraktikkan dan mengamalkan nilai-nilai yang baik dan menjauhi nilai-nilai yang buruk, dan ditujukan agar manusia mengetahui tentang cara hidup, atau bagaimana hidup seharusnya, karakter (akhlak) menjawab pertanyaan manusia tentang manakah hidup baik bagi manusia, dan bagaimanakah seharusnya berbuat, agar hidup memiliki nilai, kesucian dan kemuliaan.

Salah satu ayat Al-Qur'an tentang pendidikan karakter yakni terdapat pada Q.S. Al-Ahzab ayat 43 yang artinya : " Dia-lah yang memberi Rahmat kepadamu dan para malaikat-Nya (memohonkan ampunan untukmu), agar Dia mengeluarkan kamu dari kegelapan kepada cahaya (yang terang). Dan Dia Maha Penyayang kepada orang-orang yang beriman".

Terdapat nilai pendidikan dalam ayat tersebut, dimana setiap manusia hendaknya selalu berprilaku yang baik dalam setiap aktivitas dikehidupan sebagai manusia, mengingat telah dianugerahkannya akal pada diri seorang manusia untuk dapat mebedakan mana yang baik dan mana yang kurang baik sehingga kita dapat menentukan jalan hidup mana yang akan dipilih, yang sesuai dengan ajaran agama Islam dan sesuai dengan sumber hukum Islam yakni alQur'an dan al- Hadis.

Pendidikan yang didalamnya mengandung pengertian dengan pelatihan, pembiasaan secara terus menerus dalam rangka penanaman nilai-nilai serta pengaplikasian sikap yang berkarakter yang baik dari seorang individu ini juga memerlukan dukungan dan kerja sama yang harmonis diantara tiga pilar utama pendidikan, yaitu rumah, sekolah dan masyarakat, serta dengan menggunakan seluruh lokus pendidikan, yaitu:

1. Sekolah sebagai wahana aktualisasi nilai

2. Setiap perjumpaan adalah momen pendidikan nilai

3. Manajemen kelas yang berbasis akhlak mulia

4. Penegakan tata tertib, disiplin dan kode etik sekolah

5. Pendampingan dan perwalian yang efektif dan intensif

6. Pendidikan agama yang transformatif dan efektif

7. Pendidikan estetika untuk memperhalus budi pekerti

8. Pendidikan jasmani untuk melatih kerja sama dan sportivitas

9. Pengembangan kurikulum yangberbasis pada pendidikan karakter. ${ }^{8}$

Berdasarkan hal tersebut jelaslah bahwa dalam hal pendidikan bukan hanya sekolah sebagai satu-satunya lembaga yang bertanggung jawab terhadap

${ }^{7}$ Murtadha Muthahhari, Pengantar Ilmu-Ilmu Islam, Jakarta: Pustaka al-Zahra, 2003, h. 263.

8 Doni Koesuma, Pendidikan Karakter Strategi Mendidik di Zaman Global , Jakarta: Grasindo, 2007, h. 224-268. 
baik atau buruknya karakter seorang anak, tetapi ada juga pendidikan dirumah dan pendidikan dimasyarakat yang memiliki peran tak kalah penting dalam pembentukan karakter seorang anak.

\section{Pilar-pilar Pendidikan moral}

Berbagai kenyataan dan realitas yang menjadi penghambat bagi terlaksananya pendidikan moral, pendidikan nilai, pendidikan agama dan pendidikan kewarganegaraan sebagai pilar-pilar pendukung pendidikan karakter tersebut kian hari tampak semakin parah dan lemah. Keadaan ini jika tidak segera diatasi maka pendidikan karakter yang diharapkan dapat mengatasi kemerosotan moral dan akhlak bangsa ini akan sulit diwujudkan. Karenanya sebuah studi komprehensif, mendalam dan sungguh-sungguh untuk merekontruksi kembali pendidikan karakter yang didasarkan kepada hasil penelitian yang kredibel merupakan hal yang perlu dilakukan.

Selanjutnya realisasi pendidikan karakter tersebut juga harus ditopang oleh tiga pilar utama lembaga pendidikan, yaitu rumah tangga, sekolah dan masyrakat (negara). ${ }^{9}$ Pendidikan dirumah tangga dilakukan oleh orang tua dan anggota keluarga terdekat lainnya dengan dasar tanggung jawab moral keagamaan, yakni menganggap bahwa anak adalah titipan dan amanah dari Tuhan yang harus dipertanggung jawabkan. Salah satu contoh tindakan yakni dengan mengikat seorang anak dengan kepribadian Rasulullah Saw, serta meneladani beliau dan menanamkan kecintaan terhadapnya, karena Rasulullahlah contoh yang tepat dimana orang tua menginginkan seorang anak yang berakhlak/ berkarakter mulia. Seperti yang terdapat dalam sebuah hadis yang artinya "Didiklah anak-anak kalian terhadap tiga hal; kecintaan kepada Nabi kalian, kecintaan kepada keluarga beliau, dan membaca Al-Qur'an”. Keterikatan anak dengan Rasulullah akan menjadikannya sebagai manusia yang lurus, sebab dengan begitu seornag anak akan terbuka akal pikirannya untuk mengikuti perjalanan Rasulullah. ${ }^{10}$

Namun, dalam praktiknya tidak semua orang tua memiliki wawasan, pengalaman, keahlian dan pemahaman tentang pedagogi, sehingga peran-peran yang harus dimainkan orang tua dalam mendidik karakter putra-putrinya tidak dapat berjalan sebagaimana mestinya. Keadaan ini masih ditambah lagi dengan keadaa orang tua yang tidak memiliki waktu yang cukup untuk membina karakter anaknya dirumah, sebagai akibat dari perannya yang tidak lagi hanya bersikap domestik dan lokal, melainkan juga peran yang bersifat nasional, regoinal bahkan internasional.

Berbagai kekurangan yang dimiliki oleh orang tua dirumah, maka pendidikan karakter selanjutnya diserahkan kepada sekolah, dengan pertimbangan selain karena merupakan institusi yang dibangun dengan tugas utamanya mendidik karakter bangsa, juga di sekolah terdapat infrastruktur,

\footnotetext{
9 Abudin Nata, Studi Islam Komprehensif, Jakarta: Prenada Media, 2010, Cet-1, h. 89-101

10 Muhamad Suwaid, Mendidik Anak Bersama Nabi, Solo: Pustaka Arafah, 2004, h.510.
} 
sarana prasarana, SDM, manajemen, sistem dan lain sebagainya yang berkaitan dengan urusan pendidikan. Namun, karena tidak semua sekolah memiliki visi, misi, tujuan dan komitmen yang jelas tentang pendidikan karakter, serta lemahnya dalam menerapkan metodologi dan pendekatan sebagaimana tersebut di atas, menyebabkan pendidikan karakter disekolah juga tidak berjalan sebagaimna mestinya. ${ }^{1}$

Melihat kenyataan yang telah disebutkan di atas, maka pemerintah dan masyarakat juga harus bertanggung jawab terhadap pendidikan karakter. Melalui tanggung jawab, otoritas, dana, fasilitas, sumber daya manusia dan sistem yang dimilikinya, pemerintah memiliki peluang yang lebuh besar untuk menyelenggarakan pendidikan karakter bangsa. Namun demikian, pilar pemerintah inipun dalam keadaan rapuh dan kurang efektif. Banyaknya pejabat pemerintah mulai dari atas sampai kebawah, mulai dari pusat sampai kedaerah yang terlibat dalam tindakan korupsi, penyalahgunaan jabatan dan wewenang yangn berdampak pada kerusakan lingkungan, serta adanya sejumlah kebijakan yang dinilai tidak berpihak pada masyarakat kecil, serta pola hidup yang foyafoya, menyebabkab wibawa dan hak moral pemerintah sebagai modal utama bagi pendidikan karakter menjadi amat merosot.

Melihat adanya kenyataan yang demikian ini memperlihatkan kenyataan bahwa pendidikan karakter merupakan sebuah keniscayaan bagi keberlangsungan masa depan bangsa yang beradab, berbudaya dan bermartabat. Dengan tercapaianya pendidikan karakter, maka selain akan menciptakan sebuah kehidupan yang semakin tertib, aman, nyaman dan sejahtera, juga akan dapat meningkatkan harkat dan martabat bangsa, yang pada gilirannya akan menimbulkan rasa hormat dan daya tarik bangsa-bagsa lain di dunia.

Sudah kewajiban bagi kita seluruh aspek pendidikan baik keluarga, sekolah dan masyarakat sama-sama memperbaiki perannya, sadar akan tugas dan tanggung jawabnya dengan tujuan yang mulia yakni menciptakan generasi penerus bangsa yang berkarakter mulia sesuai dengan ajaran dan syaria't Islam.

\section{Nilai-nilai Pendidikan Karakter}

Menurut Departemen Pendidikan Nasional, mulai tahun 2011, seluruh pendidikan di Indonesia harus menyisipkan nilai-nilai pendidikan berkarakter kepada para siswa dalam proses pendidikannya. Terdapat 18 nilai pendidikan karakter, yaitu:

a. Religius, yakni sikap yang patuh dalam melaksanakan ajaran agama yang dianutnya, toleransi terhadap pelaksanaan ibadah lain, dan hidup rukun dengan pemeluk agama lain.

b. Jujur, yakni perilaku yang didasarkan pada upaya menjadikan dirinya sebagai orang yang selalu dapat dipercaya dalam perkataan, tindakan dan pekerjaan.

${ }^{11}$ Abudin Nata, Kapita Selekta Pendidikan Islam, Jakarta: Raja Grafindo Persada, 2013, h. 154155. 
c. Toleransi, suatu sikap dan tindakan yang menghargai perbedaan agama, suku, etnis, pendapat, sikap, dan tindakan orang lain yang berbeda darinya.

d. Disiplin, yakni tindakan yang menunjukkan perilaku tertib dan patuh pada berbagai ketentuan dan paraturan.

e. Kerja Keras, yakni suatu tindakan yang menunjukkan perilaku tertib dan patuh pada berbagai ketentuan dan peraturan.

f. Kreatif, yakni berfikir dan melakukan sesuatu untuk menghasilkan cara atau hasil yang baru dari sesuatu yang telah dimiliki.

g. Mandiri, yakni sikap dan perilaku yang tidak mudah tergantung pada orang lain dalam menyelesaikan tugas-tugas.

h. Demokratis, yakni cara berfikir, bersikap, dan bertindak yang menilai sama hak dan kewajiban dirinya dan juga orang lain.

i. Rasa Ingin Tahu, yakni sikap atau tindakan yang berupaya untuk mengetahui lebih mendalam dan meluas dari sesuatu yang dipelajarinya, dilihat dan didengarnya.

j. Semangat Kebangsaan, yakni cara berfikir, bertindak dan berwawasan yang menempatkan kepentingan bangsa dan negara di atas kepentingan diri dan kelompoknya.

k. Cinta Tanah Air, yakni cara berfikir, bertindak dan berwawasan yang menenmpatkan kepentingan bangsa dan negara di atas kepentingan diri dan kelompoknya.

1. Menghargai Prestasi,yakni sikap dan tindakan yang mendorong dirinya untuk menghasilkan sesuatu yang berguna bagi masyarakat, dan mengakui serta menghormati keberhasilan orang lain.

m. Bersahabat/ Komunikatif, yakni sikap atau tindakan yang mendorong dirinya untuk menghasilkan sesuatu yang berguna bagi masyarakat, dan mengakui serta menghormati keberhasilan orang lain.

n. Cinta Damai, yakni sikap dan tindakan yang mendorong dirinya untuk menghasilkan sesuatu yang beerguna bagi dirinya, bagi masyarakat dan mengakui serta menghormati keberhasilan orang lain.

o. Gemar Membaca, yakni kebiasaan dan menyediakan waktu untuk membaca berbagai macam bacaan demi kebajikan dirinya.

p. Peduli Lingkungan, yakni sikap dan tindakan yang selalu berupaya mencegah dari kerusakan alam dilingkungan alam sekitarnya, dan mengembangkan upaya-upaya perbaikan terhadap alam yang telah terjadi kerusakan.

q. Peduli Sosial, yakni sikap dan tindakan yang selalu ingin memberi bantuan kepada masyarakat dan orang lain yang membutuhkan.

r. Tanggung Jawab, yakni sikap dan perilaku seseorang dalam melaksanakan tugas dan kewajibannya, yang seharusnya dia lakukan, terhadap diri sendiri, masyarakat, lingkungan, alam, budaya, bangsa dan negara serta Tuhan Yang Maha Esa. 
Nilai-nilai karakter yang tersebut di atas, hendaknya tertanam didalam diri para generasi muda Indonesia melalui sebuah proses pendidikan yang dilaksanakan secara tepat yang didukung pula oleh tenaga-tenaga pendidik yang profesional. Karena pendidikan dalam rangka membentuk karakter generasi sebagai generasi peneris bangsa ini juga memiliki prinsip-prinsip pendidikan berdasarkan ajaran Islam, seperti yang dikatakan oleh Mohammad Athiyah alAbrasyi dalam bukunyan al-Tarbiyah al-Islamiyah. Dia mengatakan bahwa pendidikan Islam ialah pendidikan yang ideal. Hal tersebut antara lain didasarkan pada adanya prinsip kebebasan dan demokrasi dalam pendidikan, pembentukan akhlak mulia sebagai tujuan utama pendidikan Islam, berbicara manusia sesuai dengan akalnya, menggunakan metode yang berbeda-beda dalam pengajaran, pendidikan Islam adalah pendidikan bebas, sistem pendidikan individu dalam pendidikan Islam, memberikan perhatian atas pembawaan insting seseorang dalam tuntunan kebidang-bidang karya yang dipilihnya, mencintai ilmu dan menyediakan diri untuk belajar, memberikan perhatian terhadap cara-cara berpidato, berdebat dan kelancaran lidah, memberikan pelayanan terhadap anakanak secara halus, memberikan perhatian terhadap sistem universitas rakyat, dan perhatian terhadap perpustakaan untuk merangsang penelitian dan pembacaan. ${ }^{12}$

To achieve the goal of educational character, this agency implementing an education strategy in which the life of the lodge with all its totality a medium of learning and education itself, the elements forming the values of Pesantren (islamic boarding), both human and infrastructure both physical and nonphysical, directed to support the creation of an educational environment so that as a whole is designed for the benefit of the community-based character education, so that all has been heard, seen, felt, done, and experienced by the students and even the whole of the schools is intended to achieve educational goals, yang maksudnya bahwa Untuk mencapai tujuan karakter pendidikan, lembaga ini menerapkan strategi pendidikan di mana kehidupan pondok dengan semua totalitasnya media pembelajaran dan pendidikan itu sendiri, unsur-unsur yang membentuk nilai-nilai Pesantren (islamic boarding), baik manusia dan infrastruktur baik fisik dan non-fisik, diarahkan untuk mendukung terciptanya lingkungan pendidikan sehingga secara keseluruhan dirancang untuk kepentingan pendidikan karakter berbasis masyarakat, sehingga semua telah mendengar, melihat, merasa, dilakukan, dan dialami oleh mahasiswa dan bahkan seluruh sekolah dimaksudkan untuk mencapai tujuan pendidikan ${ }^{13}$

\footnotetext{
12 Abudin Nata, Ilmu Pendidikan Islam, Jakarta: Kencana, 2010, h. 103.

13 M. Ihsan Dacholfany, Leadership Style in Character Education at The Darussalam Gontor Islamic Boarding, Journal Al-Ulum, Volume 15 Number . 2December 2015, p.455
} 
Selanjutnya mengacu kepada sumber ajaran Islam dapat dijumpai prinsipprinsip pendidikan Islam yang berkaitan dengan psikologis manusia yakni sebagai berikut:

a. Prinsip Pendidikan Untuk Semua (Education For All)

Bahwa agar dalam pendidikan tidak terdapat ketidak adilan dalam perlakuan, atau diskriminasi. Pendidikan harus diberikan kepada semua orang dengan tidak membedakan karena latar belakang suku, agama, kebangsaan, status sosial, jenis kelamin, tempat tinggal dan lainnya.

b. Prinsip Pendidikan Sepanjang Hayat (Long Life Education)

Yakni prinsip yang menekankan bahwa belajar itu dilaksnakan terus menerus, walaupun telah menyandang gelar kesarjanaan. Belajar tetap harus dilaksanakan secara terus menerus krena ilmu juga berkembang sesuai dengan semakin majunya ilmu pengetahuan dan tekhnologi, sehingga yang belajar terus menerus tidak akan tertinggal.

c. Prinsip Pendidikan Yang sesuai dengan Bakat Manusia Yakni bahwa setiap manusia memiliki persamaan dan juga perbedaan dengan manusia lainnya, juga memiliki perbedaan dalam tingkat kemampuan inteltual, bakat, minat, hobi dan lainnya. Demikian pula perbedaan tingkat usia pada seseorang meyebabkan terjadinya perbedaan ciri-ciri kejiwaannya.

d. Prinsip Pendidikan yang Sesuai Dengan Perkembangan Zaman. Yakni adanya penyesuaian berbagai kebijakan dan program pendidikan sesuai dengan kebutuhan zaman, tanpa mengorbankan hal-hal yang bersifat ajaran dan prinsip. Sesuai dengan semakin majunya ilmu pengetahuan dan teknologi komunikasi dan informasi yang canggih mengharuskan pendidikan juga mampu bersaing dalam segala hal, mengingat semakin maju teknologi semakin kritis pula pemikiran manusia yang tidak ingin tertinggal dari apa yang sudah ada.

Dengan adanya kenyataan yang demikian mengharuskan pendidikan itu bersifat global shingga mampu mengimbangi kemajuan IPTEK yang semakin hari semakin maju dan terus berkembang, salah satunya untuk dapat memahami apa yang dibutuhkan manusia saat ini dan agar tetap dapat meraih apa yang menjadi tujuan pendidikan itu sendiri, salah satunya yaitu pendidikan karakter yang harus diciptakan oleh seluruh elemen dan dilakukan dengan berbagai macam cara salah satunya yakni dengan menyesuaikan dengan keadaan zaman dan kemjuan ilmu pengetahuan dan teknologi. 


\section{Pendidikan Karakter di Indonesia dalam Pandangan Psikologis}

Masyarakat Indonesia saat ini sudah berubah dari kehidupan masyarakat budaya agraris kepada masyarakat budaya industrialis dan informasi, atau masyarakat budaya kota (urban society). Pada masyarakat budaya kota ini ditandai oleh hal-hal sebagai berikut: (1). Orientasi kehidupan dimasa depan; (2). Lebih bersifat rasional, pragmatis, hedonostik; (3). Sangat menghargai waktu; (4) bekerja dengan penuh perhitungan dan perencanaan yang cermat; (5). Komunikasi banyak bertumpu pada panggunaan peralatan teknonologi komunikasi; (6) kurang memiliki waktu untuk mengerjakan-pekerjaan domestik (seperti memasak, mencuci pakaian, merawat dan menyusui bayi, mengatur rumah tangga dan sebagainya); (7). Mengikuti budaya pop atau sesuatu yang sedang in; (8). Profesional dalam bekerja; (9). Cenderung individualistik. Keadaan masyarakat yang demikian itu telah mempengaruhi cara pandang atau paradigma dalam memperlakukannya. Metode dan pendekatan dalam membentuk karakter masyarakat urban seperti itu jauh berbeda dengan metode dan pendekatan dalam membentuk karakter masyarakat agraris. ${ }^{14}$

Selain itu masyarakat Indonesia saat ini sudah semakin kritis, ingin diperlakukan secara lebih adil, demokratis, dan manusiawi. Sebagai akibat dari sangat terbukanya kesempatan pada masyarakat untuk menyatakan gagasan, pikiran serta pendapat, maka masyarakat Indonesia saat ini cenderung ingin memperoleh kebebasan yang tanpa batas, sehingga mengakibatkan adanya tindakan-tindakan yang tidak seharusnya dilakukan misalnya saja main hakim sendiri terhadap orang yang melakukan kesalahan, bertindak anarkhis dan lain sebagainya.

Masyarakat Indonesia saat ini hidup dalam era globalisasi yang juga didukung oleh teknologi informasi, seperti telepon, internet, facebook, twitter, dan lain sebagainya. Teknologi yang demikian ini sangat kuat pengaruhnya dan mengubah pola dan paradigama dalam berkomunikasi. Peran-peran saluran informasi seperti ceramah agama face to face telah digantikan dengan ceramah agama melalui berbagai peralatan teknologi informasi. Untuk menikmati ceramah agama sekarang ini tidak lagi harus datang kemasjid atau majelis taklim, melainkan cukup dari dalam ruangan atau dengan cara membeli VCD dan lain sebagainya. Perubahan ini akan mempengaruhi terhadap paradigama baru dalam menyampaikan pesan-pesan pendidikan karakter.

Dengan melihat hal ini dapat diketahui bahwa saat ini psikologi masyarakat sudah berubah. Yaitu dari psikologi masyarakat agraris menjadi psikologi masyarakat industrialis, informatis dan urban. Selain itu psikologi masyarakat Indonesia juga sudah dipengaruhi tuntutan penegakan hak-hak asasi manusia, corak pemerintah yang desentralistik, perilaku yang bebas tanpa kendali, serta peralatan teknologi informasi. Keadaan ini mengharuskan adanya

14 Abudin Nata, Ilmu Pendidikan Islam dengan Pendekatan Multidisipliner, Jakarta: Raja Grafindo Persada, 2010, h. 203-217. 
paradigma baru pendidikan karakter di Indonesia yang berbasis psikologis, yang memiliki ciri-ciri sebagai berikut.

Pertama, perlunya merumuskan metode dan pendekatan pendidikan karakter yang berbasis pada peserta didik dalam suasana yang demokratis, adil, egaliter, manusiawi dan menyenangkan. Hal ini sesuai dengan pendapat psikolog yang mengatakan, bahwa seseoranglebih suka diperlakukan secara halus daripada diperlakukan seacara kasar. Hal ini juga sejalan dengan petunjuk Rasulullah Saw agar lebih mengedepankan kemudahan daripada kesukaran (yassiru walla tu'assiru), gembirakanlah dan jangan ditakut-takuti (basysyiru wa laa tunadziru).

Kedua, perlunya mengingatkan para pendidik dengan ajaran Islam yang memandang bahwa manusia adalah makhluk yang disamping memiliki sifat buruk juga memiliki sifat yang baik. Dengan peringatan ini, maka setiap pendidikan akan memperlakukan peserta didik dengan adil, yakni tidak menganggap peserta didik selamanya dalam keadaan buruk atau sebaliknya. Dengan pandangan yang demikian itu, maka setiap guru akan memiliki optimisme, bahwa peserta didiknya dapat dibina menjadi orang yang berkarakter baik.

Ketiga, secara psikologis manusia adalah makhluk yang didalam dirinya terdapat berbagai kecenderungan psikologis atau menyukai sesuatu. Secara psikologis manusia senang terhadap hal-hal yang baru, yang lucu dan yang menggugah rasa ingin tahu. Selain itu manusia juga memiliki perasaan ingin dihargai, ingin ditemani, ingin dipuji, ingin diberikan hadiah atau sesuatu dan lain sebagainya. Keadaan psikologis manusia yang demikian itu harus digunakan sebagai pintu untuk menanamkan nilai-nilai pendidikan karakter. Kecenderungan psikologi manusia yang demikian itu telah direspons dan digunakan oleh alQur'an secara cermat dalam menanamkan nilai-nilai pendidikan karakter.

Keempat, perlunya menyajikan pendidikan karakter yang sesuai dengan karakter masyarakat yang hidup dalam budaya kota yang serba cepat, instan, rasional, pragmatis, cepat dan tepat, penggunaan peralatan teknologi informasi dan menggunakan pendekatan yang partisipatif. Dengan cara demikian, maka pendidikan karakter di Indonesia akan tetap eksis, efektif , efisien dan tetap diminati masyarakat. ${ }^{15}$

Berdasarkan hal tersebut di atas dapat dikatakan bahwa pendidikan karakter pada masyarakat Indonesia saat ini harus dirubah cara pandangnya sesuai dengan tuntutan masyarakat. Perubahan ini harus didasarkan pada tinjauan psikologis, yaitu sebuah tinjauan yang bertumpu pada pandangan, bahwa manusia adalah makhluk yang dimuliakan oleh Tuhan, makhluk yang memiliki kecenderungan positif dan negatif, makhluk yang lebih suka diperlakukan secara demokratis, egaliter, adil dan manusia sebagai makhluk yang di dalam dirinya terdapat berbagai potensi yang amat berharga, yang apabila potensi ini dapat

15 Abudin Nata, Kapita Selekta Pendidikan Islam, Jakarta: Raja Grafindo Persada, 2013, h. 204205. 
digali dan dikembangkan, maka akan berguna bagi dirinya, masyarakat, bangsa dan negaranya. ${ }^{16}$

\section{SIMPULAN}

Pendidikan karakter adalah suatu jalan atau upaya yang penting untuk dilakukan dalam sebuah sistem dalam dunia pendidikan kita, dalam rangka mencetak generasi muda penerus bangsa yang telah disebutkan dalam UndangUndang, yang tidak hanya cakap serta unggul dalam keilmuannya, melainkan juga memiliki karakter/ watak yang sesuai dengan nilai-nilai luhur agama Islam.

Pendidikan karakter di Indonesia dalam tinjauan psikologis adalah pendidikan karakter yang didasarkan atau bertolak dari keadaan psikologi manusia yang hidup di era globalisasi atau masyarakat urban. Untuk mendukung terlaksananya paradigma baru pendidikan karakter tersebut perlu dirumuskan kembali. Visi, misi, tujuan, arah, kurikulum, proses belajar mengajar, kriteria guru, sarana dan prasarana dan berbagai komponen pendidikan karakter lainnya perlu dirumuskan kembali sesuai dengan berbagai tantangan yang terjadi di era globalisasi yangsedang kita hadapi saat ini.

Tidak hanya sekolah sebagai tempat atau sarana untuk ditanamkannya sebuah nilai-nilai karakter bagi siswa, melainkan semua aspek termasuk lingkungan serta rumah dimana si anak lebih banyak menghabiskan waktunya. Apabila ketiga pusat pendidikan tersebut telah mampu menjalankan sesuai dengan ranahnya masing-masing, maka seorang generasi muda yang cerdas dan juga berkarakter mulia tidak mustahil akan terlahir di Indonesia.

\section{DAFTAR PUSTAKA}

Abudin Nata, Ilmu Pendidikan Islam dengan Pendekatan Multidisipliner, Jakarta: Raja Grafindo Persada, 2010.

Abudin Nata, Kapita Selekta Pendidikan Islam, Jakarta: Raja Grafindo Persada, 2013.

Abudin Nata, Akhlak Tasawuf, Jakarta: Raja Grafindo Persada, 2005.

Abudin Nata, Ilmu Pendidikan Islam, Jakarta: Kencana, 2010.

Al-Qur'an dan Terjemahan Departemen Agama Republik Indonesia, Bandung: Diponegoro.

Doni Koesuma, Pendidikan Karakter Strategi Mendidik di Zaman Global, Jakarta: Grasindo, 2007. 
Fuad Nashori, Agenda Psikologi Islami, Yogyakarta: Pustaka Pelajar, 2010.

M. Ihsan Dacholfany, Leadership Style in Character Education at The Darussalam Gontor Islamic Boarding, Journal Al-Ulum, Volume 15 Number . 2December 2015.

Murtadha Muthahhari, Pengantar Ilmu-Ilmu Islam", Jakarta: Pustaka alZahra, 2003.

Toto Suryana, Cecep Alba, E. Syamsudin, Udji Asiyah, Pendidikan Agama Islam, Bandung: Tiga Mutiara, 1997

Undang- Undang Sistem Pendidikan Nasional, Jakarta: Sinar Grafika, 2007. 